\title{
Electrochemical deposition of zinc coatings from the ionic liquid based on choline chloride
}

\author{
Aleksandr Kravchenko ${ }^{1, *}$, Denis Dyachenko ${ }^{1}$, Dmitriy Polikarpov ${ }^{1}$ and Valeriy Fomichev ${ }^{2}$ \\ ${ }^{1}$ Department of Research and Testing, VNIKTINHO, Volgograd, Russian Federation \\ ${ }^{2}$ Institute of Design and Building, Volgograd State Technical University, Volgograd, Russian Federation
}

\begin{abstract}
Galvanic zinc coatings were obtained by using of electrolytes based on ionic liquid choline chloride - urea. Zinc chloride, zinc sulphate and zinc acetate were used as a sources of $\mathrm{Zn}^{2+}$ ions. Influence of zinc salt anion on morphology of deposited coatings shown. Anodic dissolution of obtained zinc coatings investigated in chloride containing aqueous solution.
\end{abstract}

\section{Introduction}

In recent years the wide use of galvanic zinc-based coatings in corrosion protection of steel construction causes a need of new electrolytes developing. Such electrolytes have to provide deposition of quality zinc coatings and have low toxic. For example one of these electrolytes is aqueous lactic acid based system [1].

For electrochemical deposition of metals and alloys non-aqueous low temperature ionic liquids are well suitable solutions $[2,3]$. Use of them allows to deposit several active metals and alloys without hydrogenation of coatings because of wide range of electrochemical stability (up to $6 \mathrm{~V}$ ), as well as to obtain nanostructures [4-6]. Among other ionic liquids, described in literature, deep eutectic solution based on mixture of choline chloride and urea with molar ratio 1:2 is most interested. The commercial name of such a system is reline "reline". The simplicity of the preparing procedure, the relatively low cost of the components in comparison with other ionic liquids are the advantages of this ionic liquid. It is worth noting that one of the problems cited in the review [4] of ionic liquids is high hygroscopicity. Research results in the work [7] show that the absorption of atmospheric moisture by the reline system is reversible with prolonged exposure of the ionic liquid at $80{ }^{\circ} \mathrm{C}$, which allows to work with electrolytes based on it without use inert atmosphere.

The process of cathodic deposition of zinc and its alloys from reline has been studied in recent years by many scientific groups, and qualitative, functional coatings of pure zinc, Zn-Sn, Zn-Co, Zn-Ni, Zn-Mn alloys have been obtained [8-11], and a number of other double alloys. However, in all works, zinc is introduced into the ionic liquid as zinc (II) chloride. An exception is the work [12] on the study of the electroreduction of metals, including zinc, from oxides. In the present work the investigation of electrochemical deposition and anodic dissolution of zinc coatings are shown for electrolytes based on chloride, sulfate and acetic zinc salts.

\section{Experimental}

\subsection{Chemicals and Instrumentation}

Zinc chloride (pur.), zinc sulfate heptahydrate (pur.), zinc acetate dehydrate (pur.), urea (p.a.) and choline chloride were used in present work. $\mathrm{ChCl}$ was being dried under vacuum at $80^{\circ} \mathrm{C}$ until complete drying. Ionic liquid was being prepared by mixing of $\mathrm{ChCl}$ and urea with molar ratio of $1: 2$ under vacuum at $80^{\circ} \mathrm{C}$ until a homogeneous, colorless liquid formed. For electrolyte preparing zinc salts were added to $\mathrm{ChCl}$-urea system until $50 \mathrm{mM}$ and $250 \mathrm{mM}$ concentration. Solutions were being contained under vacuum at $80^{\circ} \mathrm{C}$ for 24 hours until complete dissolution.

Electrochemical investigations as well as deposition were carried out used three-electrode cell using the Elins P-20X electrochemical workstation. Copper wire with a diameter of $1 \mathrm{~mm}$ and copper plates with dimensions of 40x10x1 mm were used as working electrodes. Spectral clean graphite electrode was used as counter electrode. A silver wire immersed in $\mathrm{ChCl}$-urea with $0,1 \mathrm{M} \mathrm{AgCl}$ was used as a reference electrode. Reference electrode was separated from work solution by porous glass.

The microstructure of zinc coatings was studied by scanning electron microscopy method on the FEI Versa 3D DualBeam.

\subsection{Measurements}

All measurements were performed at $80{ }^{\circ} \mathrm{C}$ without stirring. Cyclic voltammetry (CVA) measurements were performed on a copper wire at scan rate of $20 \mathrm{mV} / \mathrm{s}$. Zinc deposition was conducted in potentiostatic mode for 1 hour. Anodic dissolution was investigated in solution of

* Corresponding author: kravchenko@,vniktinho.ru 
$\mathrm{NaCl} 5 \%$ (wt.) by anodic linear polarization at scan rate of $10 \mathrm{mV} / \mathrm{s}$. Linear polarization resistance was determined by using the polarization measurements of the current densities at the potential at -10 and $10 \mathrm{mV}$ relatively of stationary corrosion potential $\mathrm{E}_{\text {corr. }}$.

\section{Results and discussions}

Results of CVA tests are shown in Fig. 1.
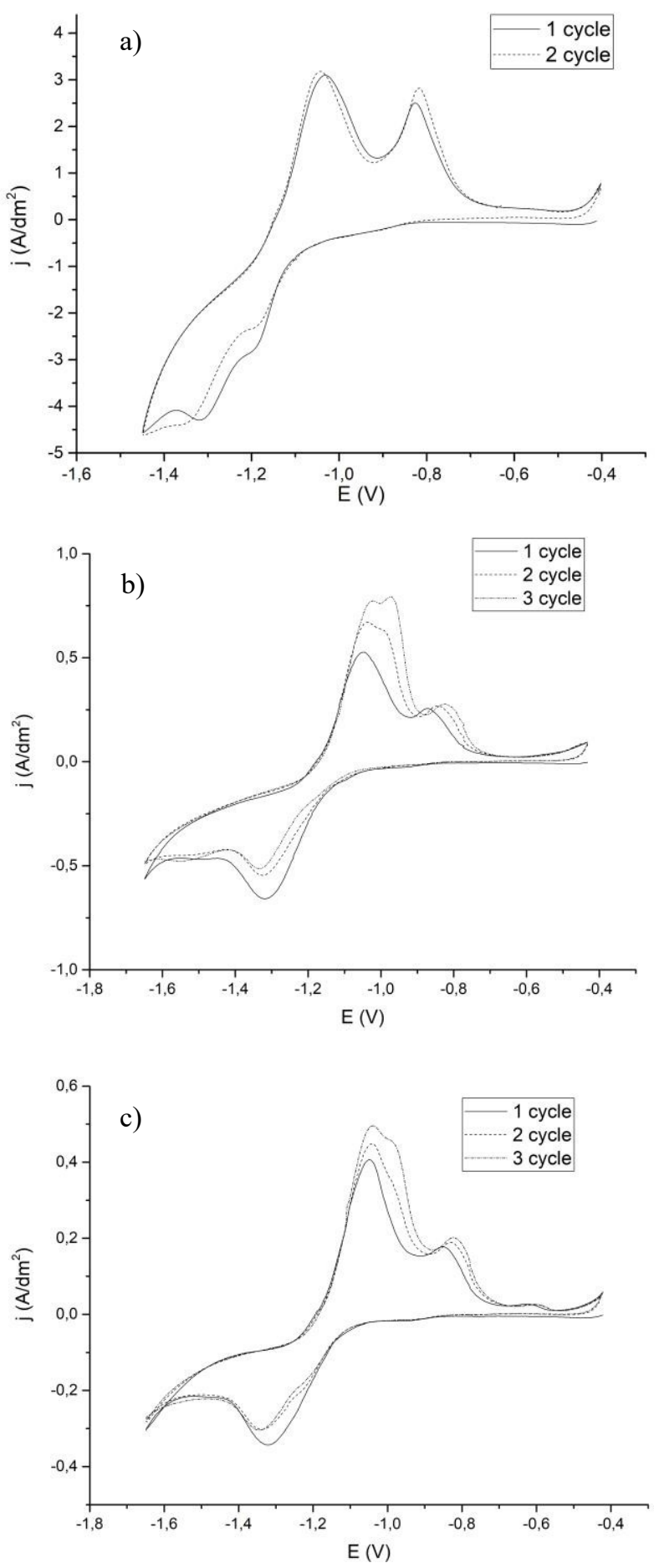

Fig. 1. CVA curves of systems with $50 \mathrm{mM}$ : $\mathrm{ZnCl}_{2}$ (a), $\mathrm{ZnSO}_{4}$ (b) and $\mathrm{Zn}\left(\mathrm{CH}_{3} \mathrm{COO}\right)_{2}$ (c).
As can be seen current density amplitudes for $\mathrm{ZnCl}_{2}$ (see fig. 1a) are higher than for $\mathrm{ZnSO}_{4}$ as well as $\mathrm{Zn}\left(\mathrm{CH}_{3} \mathrm{COO}\right)_{2}$. It can be explained using results of work [8] by higher size of complex ions of zinc that causes of their lower mobility.

Deposition of zinc was conducted at various potentials determined using results of CVA. Microstructure of obtained coatings is shown in Fig. 2-4.

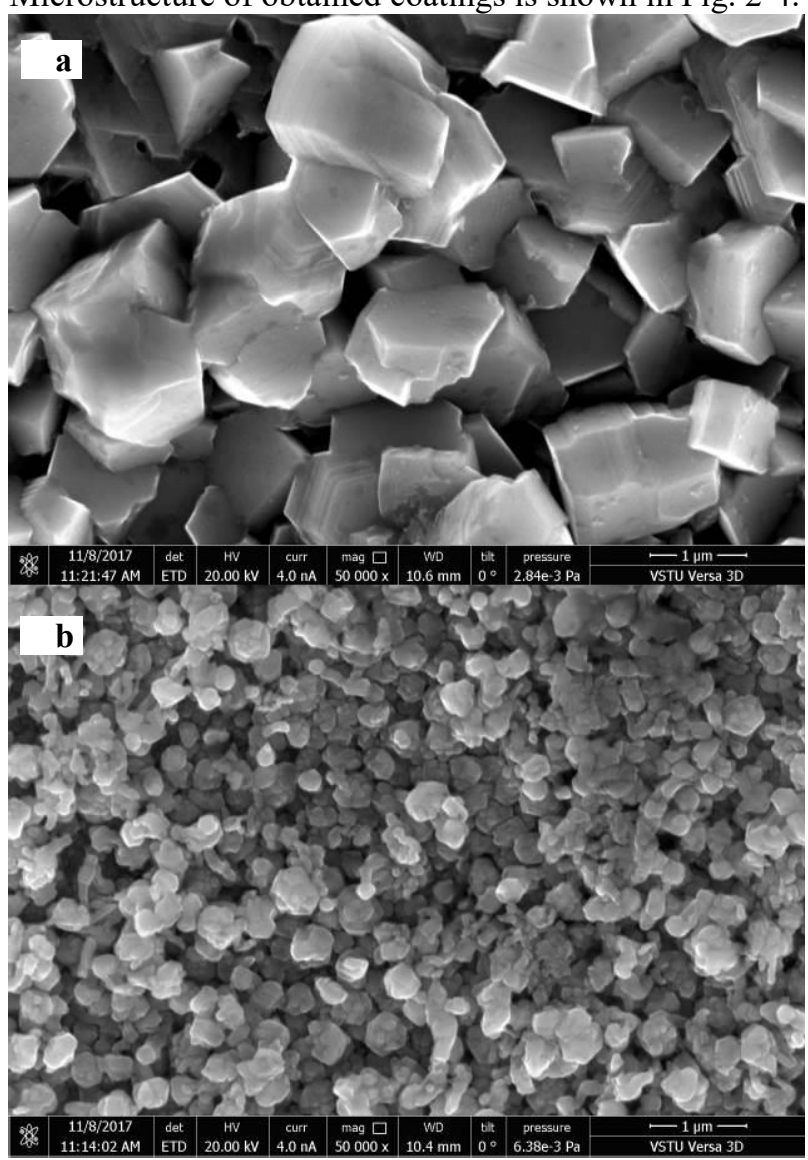

Fig. 2. SEM image of the microstructure of zinc coating deposited from electrolyte with $250 \mathrm{mM} \mathrm{ZnCl}_{2}$ at potential: a) $-1250 \mathrm{mV}$; b) $-1700 \mathrm{mV}$. Magnification is $50000 \mathrm{x}$.

As can be seen the displacement of potential to the cathodic area causes downsizing and deformation of crystallites. It can be explained by intensification of choline ion reduction proceeding at more negative potential. It can be assumed products of choline reduction accumulate in the near electrode layer and obstruct to diffusion of zinc ions as well as possess surface activity.

Fig. 3 shows that steps are formed on crystallites surface at more negative potential. A similar picture can be seen for the system with $\mathrm{Zn}\left(\mathrm{CH}_{3} \mathrm{COO}\right)_{2}$ in Fig. 4. The presence of sulfate anion leads to deformation of grains whereas the presence of acetate anion leads to flattening of them. It should be noted morphology of zinc coatings deposited in the presence various anions is actually identical at potentials up to $-1350 \mathrm{mV}$. At potentials more positive the presence of sulfate or acetate anions leads to smoothing of grain borders. 




Fig. 3. SEM image of the microstructure of zinc coating deposited from electrolyte with $250 \mathrm{mM} \mathrm{ZnSO}_{4}$ at potential: a) $-1320 \mathrm{mV}$; b) $-1550 \mathrm{mV}$. Magnification is $50000 \mathrm{x}$.

Anodic dissolution of obtained zinc coatings were conducted in solution of $\mathrm{NaCl} 5 \%$ (fig. 5). Coating obtained from electrolyte with $\mathrm{Zn}\left(\mathrm{CH}_{3} \mathrm{COO}\right)_{2}$ at potential $-1450 \mathrm{mV}$ shows the highest current density of dissolution. This coating actively dissolves in a range of potential from -750 to $-50 \mathrm{mV}$. Such activity is obviously caused the most loose microstructure that obstructs to formation of compact protective layer of zinc oxidation products. Coatings obtained from electrolyte with $\mathrm{ZnCl}_{2}$ and $\mathrm{ZnSO}_{4}$ at potential

$-1700 \mathrm{mV}$ and $-1550 \mathrm{mV}$, respectively, show least current density of dissolution. Their microstructure (fig. $2 \mathrm{~b}$ and fig. $3 \mathrm{~b}$ ) with nanoporous is compacted products of zinc oxidation: $\mathrm{ZnO}, \mathrm{Zn}(\mathrm{OH})_{2}, \mathrm{Zn}_{5}(\mathrm{OH})_{8} \mathrm{Cl}_{2} \cdot \mathrm{H}_{2} \mathrm{O}$ [8]. The formation of compact protective layer is confirmed by range of passive state which in case of electrolyte with $\mathrm{ZnCl}_{2}$ is $300 \mathrm{mV}$.

Polarization resistance $\left(R_{p}\right)$ values of zinc coatings in $\mathrm{NaCl} 5 \%$ (wt.) aqueous solution are shown in Table 1. For all coatings (except for the coating obtained at potential $-1550 \mathrm{mV}$ ) polarization resistance is in range $50-85 \mathrm{ohm}$. These results are in good accordance with obtained values for metal zinc in $\mathrm{NaCl} 5 \%$ (wt.) after exposure in solution for 2 hours [10]. Increase of exposure time up to 24 hours leads to growth of polarization resistance that can be explained by accumulate of corrosion products on a surface and in porous. In present work the exposure time of coating was 30-60 min until potential stabilization.

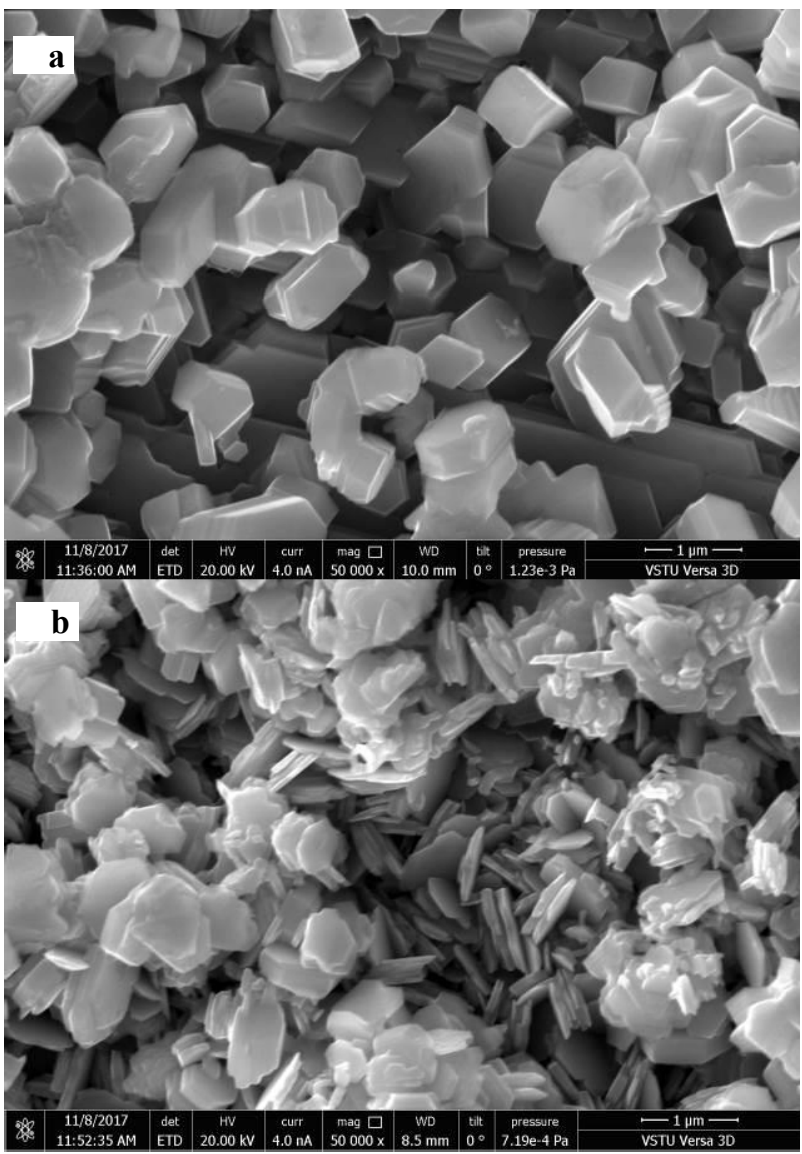

Fig. 4. SEM image of the microstructure of zinc coating deposited from electrolyte with $250 \mathrm{mM} \mathrm{Zn}\left(\mathrm{CH}_{3} \mathrm{COO}\right)_{2}$ at potential: a) $-1230 \mathrm{mV}$; b) $-1450 \mathrm{mV}$. Magnification is $50000 x$.

These results provide to conclude: coating deposited at potential $-1700 \mathrm{mV}$ has relatively high $R_{p}$ value and that corresponds to conclusions based on anodic dissolution curves. But in the case of coatings obtained at potentials $-1550 \mathrm{mV}$ and $-1450 \mathrm{mV}$ results of anodic linear polarization disagree to $R_{p}$ values. From this we can conclude that microstructure of testing zinc coatings determine a possibility of surface passivation at large deviate from stationary potential, whereas in the vicinity of $E_{\text {corr }}$ corrosion rate doesn't depend on the size and shape of zinc grains.

Table 1. Polarisation resistance values of zinc coatings in solution containing $\mathrm{NaCl} 5 \%$ (wt.).

\begin{tabular}{|c|c|c|}
\hline $\begin{array}{c}\text { Coating } \\
\text { system }\end{array}$ & $\begin{array}{c}\text { Deposition } \\
\text { potential (E vs. } \\
\text { Ag wire), mV }\end{array}$ & $\begin{array}{c}\text { Polarization } \\
\text { resistance } \mathbf{R}_{\mathbf{p}}, \\
\text { ohm }\end{array}$ \\
\hline \multirow{2}{*}{$250 \mathrm{mM} \mathrm{ZnCl} 2$} & -1250 & 53 \\
\cline { 2 - 3 } & -1700 & 81 \\
\hline \multirow{2}{*}{$250 \mathrm{mM} \mathrm{ZnSO}_{4}$} & -1320 & 53 \\
\cline { 2 - 3 } & -1550 & 17 \\
\hline
\end{tabular}




\begin{tabular}{|c|c|c|}
\hline $\begin{array}{c}\text { Coating } \\
\text { system }\end{array}$ & $\begin{array}{c}\text { Deposition } \\
\text { potential (E vs. } \\
\text { Ag wire }), \mathbf{m V}\end{array}$ & $\begin{array}{c}\text { Polarization } \\
\text { resistance } \mathbf{R}_{\mathbf{p}}, \\
\text { ohm }\end{array}$ \\
\hline \multirow{2}{*}{$\begin{array}{c}250 \mathrm{mM} \\
\mathrm{Zn}\left(\mathrm{CH}_{3} \mathrm{COO}\right)_{2}\end{array}$} & -1230 & 75 \\
\cline { 2 - 3 } & -1450 & 83 \\
\hline
\end{tabular}

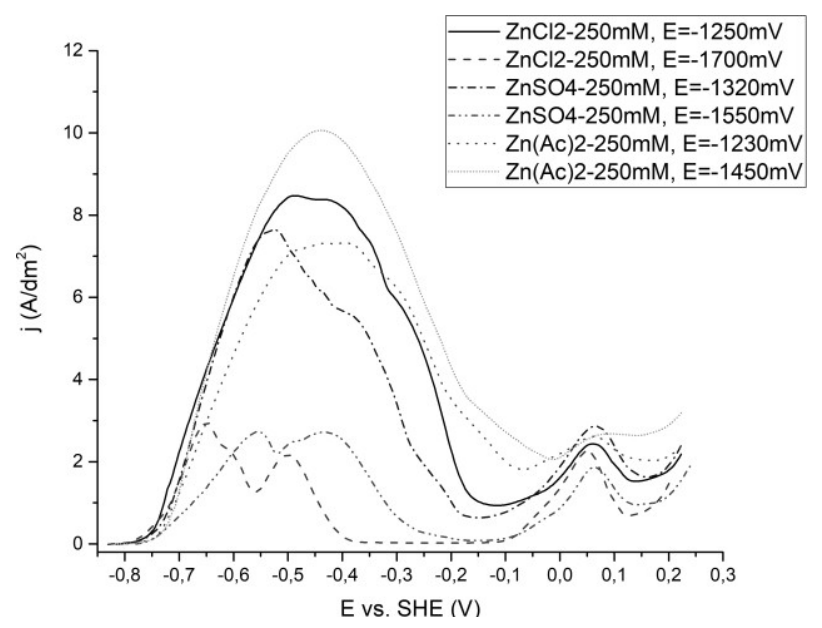

Fig. 5. Anodic dissolution of various zinc coatings in solution of $\mathrm{NaCl} 5 \%$ (wt.) at $25^{\circ} \mathrm{C}$.

\section{Conclusions}

1. The use of $\mathrm{ZnSO}_{4}$ and $\mathrm{Zn}\left(\mathrm{CH}_{3} \mathrm{COO}\right)_{2}$ for preparing of zinc-plating electrolytes based on ionic liquid choline chloride - urea leads to decrease of zinc reduction potential, increase of diffusion control. That provides to reduce of deposition rate for obtaining thin films.

2. Using of electrolytes based choline chloride - urea with $\mathrm{ZnSO}_{4}$ and $\mathrm{Zn}\left(\mathrm{CH}_{3} \mathrm{COO}\right)_{2}$ leads to downsizing and flattening of crystallites. Addition of $\mathrm{Zn}\left(\mathrm{CH}_{3} \mathrm{COO}\right)_{2}$ leads to obtaining of zinc coating that has actively surface.

3. Investigated electrolytes allow forming coatings with the grain size of the order of $500 \mathrm{~nm}$.

4. Coatings obtained from electrolyte with $\mathrm{ZnCl}_{2}$ and $\mathrm{ZnSO}_{4}$ at potential $-1700 \mathrm{mV}$ and $-1550 \mathrm{mV}$, respectively, show the passive region on the anodic polarization curve in the $\mathrm{NaCl} 5 \%$ solution at the large deviate from $\mathrm{E}_{\text {corr }}$. Results of polarization resistance evaluation allow to conclude the corrosion rate in the vicinity of $E_{\text {corr }}$ doesn't depend on the size and shape of zinc grains and it is requires a study another potential factors.

\section{References}

1. S.Y. Kireev, Y.P. Pereligin, A.Y. Kireev, Universy proceedings. Volga region. Technical sciences. 2(10), 201 (2009)

2. F. Liu, Y. Deng, X. Han, W. Hu, C. Zhong, J. Alloys Compd., 654, 163 (2016)
3. A. Ispas, C.A. Vlaic, M. Camargo, A. Bund, ECS Transactions, 75 (15), 657 (2016)

4. M. Galinski, A. Lewandowski, I. Stepniak، Electrochim. Acta, 51, 5567 (2006)

5. F. Endres, M. Bukowski, R. Hempelmann, H. Natter, Angew. Chem. Int. Ed., 42, 3428 (2003)

6. A. P. Abbott, K. El Ttaib, K. S. Ryder, E. L. Smith, Transactions of the IMF, 86 (4), 234 (2008)

7. C. Du, B. Zhao, X.-B. Chen, N. Birbilis, H. Yang, Sci. Rep., 6 (1), 29225 (2016)

8. A. P. Abbott, G. Capper, D. L. Davies, R. K. Rasheed, P. Shikotra, Inorg. Chem., 44 (19), 6497 (2005)

9. Y. Hamlaoui, F. Pedraza, L. Tifouti, Am. J. Sci., 4 (7), 430 (2007)

10. S. Song, Zh. Chen. Int. J. Electrochem. Sci., 8, 6851- 6863 (2013) 